\title{
ARTIKKELIT
}

\section{ע Vanhuspalvelut ja valinnanvapaus - johtavien viranomaisten näkemyksiä palvelusetelistä}

\author{
Olli Karsio $^{1}$ \\ Lina Van Aerschot ${ }^{1}$
}

${ }^{1}$ Yhteiskuntatieteiden tiedekunta, Tampereen yliopisto

\begin{abstract}
Palveluseteli on yksi vanhuspalveluiden markkinoistamisen väline. Kunnat saavat päättää sen käyttöönotosta ja käytön ehdoista lain sallimissa rajoissa melko vapaasti. Tämä on johtanut siihen, että kunnissa on hyvin erilaisia ratkaisuja ja lähestymistapoja palvelusetelin käyttöön. Palveluseteli voidaan ottaa käyttöön vain yhdessä tai lukuisissa palveluissa, sitä voidaan tarjota kaikille tiettyyn palveluun oikeutetuille tai erilaisin perustein vain joillekin heistä. Tässä artikkelissa tarkastellaan paikallisten johtavien viranomaisten haastattelujen perusteella, millaiseksi vanhuspalvelujen järjestämisen välineeksi palveluseteli kunnissa ymmärretään sekä minkälaisin perusteluin ja tavoittein palveluseteleitä on otettu käyttöön. Tutkimuksemme perusteella kunnissa käytetään palveluseteliä asiakkaiden ja palveluntuotannon ohjailun sekä kustannussäästöjen välineenä. Paikalliset markkinat ovat olennainen tekijä, sillä ilman toimivia markkinoita palveluseteli ei tarjoa todellisia valinnan mahdollisuuksia. Palvelusetelin mahdollistamaa valinnanvapautta pohditaan asiakkaan kannalta eri tavoin. Joissakin kunnissa huonokuntoisimpien vanhusten ei ajatella kykenevän valintoihin. Asiakkaan toimintakyvyn ja kunnon lisäksi palveluseteleitä voidaan kohdentaa maksukyvyn perusteella vain hyvätuloisille. Vaihtoehtoisesti palvelusetelistä voidaan tehdä tulosidonnainen, jolloin yksityisten palvelujen käyttö on aidosti mahdollista myös pienituloisille.
\end{abstract}

\section{Johdanto}

Sosiaali- ja terveyspalvelujen uudistamisessa on viime vuosina korostettu valinnanvapautta. Sen lisääminen on yksi meneillään olevan SOTE-uudistuksen keskeisimpiä tavoitteita. Palveluseteli on yksi väline, jolla valinnanvapautta voidaan lisätä julkisesti rahoitettujen palvelujen käyttäjille. Palveluseteleitä voidaan tarjota silloin, kun kuntalainen on oikeutettu julkisiin palveluihin. Kunnan tuottaman palvelun sijasta hän voi valita palveluntuottajan yksityiseltä sektorilta ja maksaa kustannukset palvelusetelillä joko kokonaan tai kunnan ennalta määrittämään rajaan asti. 
Erityisesti vanhusten palveluissa on viime vuosina pyritty lisäämään apua tarvitsevien ja palveluja käyttävien ihmisten mahdollisuuksia valita haluamansa palvelu ja sen tuottaja. Valinnanvapaus nähdään keinona lisätä ihmisten mahdollisuuksia vaikuttaa itseään koskeviin asioihin. Palveluseteli on ollut yksi väline valinnanvapauden lisäämiseen.

Ajatuksen palvelusetelistä esitteli alun perin Milton Friedman (1955), kun hän ehdotti 1950-luvulla, että USA:n koululaitos uudistettaisiin jakamalla oppilaille palvelusetelit ja antamalla perheiden valita mihin kouluun he lapsensa laittavat. Myöhemmin Friedman on tarkentanut, että palvelusetelit eivät ole päämäärä itsessään vaan keino, jonka avulla valtion roolia pienennetään ja markkinoiden toimintaa vahvistetaan (Friedman 1997). Palveluseteli toimiikin valinnanvapauden lisäämisen ohella myös keinona yksityisesti tuotettujen palvelujen käytön lisäämiseen (Ascoli \& Ranci 2003, 6; Laki sosiaali- ja terveydenhuollon palvelusetelistä 569/2009). Tätä perustellaan tehokkuudella: ajatuksena on, että kun palveluntuottajat kilpailevat palveluseteliasiakkaista, niiden on tuotettava laadukkaita ja kohtuuhintaisia palveluja (Daniels \& Trebilcock 2005).

Palveluseteleitä on käytetty eri maissa palvelujen käyttäjien ohjaamisessa julkiselta sektorilta yksityiselle, yksityisen palveluntarjonnan vahvistamisessa ja ylipäätään palvelujärjestelmän osana. Esimerkiksi Etelä-Koreassa palveluseteleitä käytetään kotihoidossa (Oh 2015). Bangladeshissa köyhille naisille tarjotaan palveluseteleitä, joilla saa terveydenhoitoa raskausaikana, synnytyksessä ja sen jälkeen (Nguyen ym. 2012). Belgiassa on käytössä palveluseteli kotitaloustöihin (Defourny, Henry, Nassaut \& Nyssens 2010). Ruotsissa ja Chilessä niitä käytetään kouluissa (Carnoy 1998).

Euroopassa varsinaisia palvelusetelijärjestelmiä ei ole juurikaan käytössä sosiaali- ja terveyspalveluissa. Kuitenkin useissa maissa on käytössä systeemejä, joissa hoivapalvelujen hankkimiseen allokoidaan rahaa. Hollannin henkilökohtainen budjetti (personal budgets), Irlannin home care grants ja Britannian direct payments ovat kaikki järjestelmiä, joissa vanhuksille tai muille hoivaa tarvitseville annetaan palvelujen sijasta rahaa avun hankkimiseen (Kremer 2006; Timonen, Convery \& Cahill 2006; Newbronner ym. 2011). Myös Ruotsin asiakasvalintamalli (kundval), jossa palvelunkäyttäjä valitsee julkisesti rahoitetulle palvelulle haluamansa palveluntuottajan, muistuttaa palvelusetelijärjestelmää ja toimii osin myös vanhusten hoivassa (Erlandsson, Storm, Stranz, Szebehely \& Trydegård 2013). Tanskassa vanhusten kotihoidossa on olemassa palvelusetelimalli, mutta sitä on käytetty marginaalisesti (Bertelsen \& Rostgaard 2013, 137). Suomessa palveluseteliä pilotoitiin 1990luvulla ja 2000-luvun alkuvuosina alueellisesti. Vuodesta 2009 alkaen lainsäädäntö on mahdollistanut palvelusetelien käytön lähes kaikissa kuntien järjestämisvastuulla olevissa sosiaali- ja terveyspalveluissa. Suomalainen palvelusetelijärjestelmä, joka on kuntatasolla melko vapaasti toteutettavissa, on kansainvälisesti ainutlaatuinen.

Tässä artikkelissa palveluseteliä tutkitaan kuntien, ja erityisesti kunnan johtavien viranhaltijoiden näkökulmasta. Tutkimuksessa kysytään, millaiseksi vanhuspalvelujen järjestämisen välineeksi palveluseteli kunnissa ymmärretään sekä miten sen käyttöönottoa perustellaan.

\section{Valinnanvapaus vanhuspalveluissa herättää kysymyksiä}

Suomessa valinnanvapauden monipuolistuminen on asetettu sosiaali- ja terveydenhuollon uudistamisen tavoitteeksi esimerkiksi pääministeri Sipilän hallitusohjelmassa (Hallitusohjelma 2015, 28). Valmisteilla olevassa SOTE-uudistuksessa valinnanvapauden on suunniteltu koostuvan suoran valinnan palveluista, maakunnan liikelaitoksen valinnasta sekä asiakassetelillä ja henkilökohtaisella budjetilla saatavista palveluista. Asiakasseteli tai 
henkilökohtainen budjetti voitaisiin uudistuksen toteutuessa myöntää palvelutarpeen arvioinnin perusteella (Hallituksen esitys 47/ 2017). Asiakassetelillä tarkoitetaan käytännössä samaa asiaa kuin palvelusetelillä, vain nimi on muuttunut. Nimen muutokseen on kuitenkin myös syy. Se mahdollistaa setelien käytön uusin tavoin eikä soveltaminen ole sidottu palveluseteliä koskevaan lainsäädäntöön. Uudistuksen myötä järjestämisvastuu ja samalla päätökset setelien myöntämisestä siirtyisivät kunnilta maakunnille ja niiden liikelaitoksille sekä uusille SOTE-keskuksille. Tässä artikkelissa emme puhu asiakassetelistä muutoin kuin SOTE-uudistuksen yhteydessä. Oma tutkimuksemme ja käyttämämme tutkimuskirjallisuus käsittelevät palveluseteliä.

Asiakassetelillä ja henkilökohtaisella budjetilla tarkoitetaan palvelua ja palveluostoja, jotka maakunta korvaisi yksityiselle palveluntuottajalle maakunnan ennalta määräämään arvoon asti. Asiakassetelillä tarkoitetaan järjestelyä, jossa asiakassetelin käyttäjä voi valita yksityisen palveluntuottajan maakunnan hyväksymien palveluntuottajien joukosta, aivan kuten palveluseteliasiakas voi valita palveluntuottajan kunnan listaamasta joukosta. Asiakassetelin käyttäjän maksettavaksi jäisi sosiaali- ja terveydenhuollon asiakasmaksuista annetun lain mukainen asiakasmaksu, eikä palveluntuottaja saisi periä palvelunkäyttäjältä maksuja asiakassetelillä annettavista palveluista. Palvelunkäyttäjä voisi kuitenkin ostaa palveluntuottajalta lisäpalveluita omakustanteisesti. Henkilökohtainen budjetti puolestaan on käytäntö,jossa palvelunkäyttäjä saisi valita vapaasti, mistä ja miten palvelut hankkii ja mahdollisesti vaikuttaa myös palvelun sisältöön. Myöskään henkilökohtaisen budjetin perusteella annettavista palveluista palveluntuottaja ei saisi periä palvelunkäyttäjältä maksuja. Asiakasseteliä suunnitellaan lyhytaikaista ja kiireetöntä palveluntarvetta varten, ja henkilökohtaista budjettia pitkäkestoista ja jatkuvaa palveluntarvetta varten. (HE 47/2017.)
Valintojen ajatellaan edistävän ihmisten hyvinvointia sekä takaavan laadukkaan ja kustannustehokkaan palveluntuotannon parhaalla tavalla (Clarke, Newman \& Westmarland 2008; Fotaki 2009). Tämä perustuu ajatukseen, että ihmisten toimintaa ohjaavat rationaaliset ja individualistiset motiivit ja että ihmiset pystyvät parhaiten edistämään hyvinvointiaan valintojen kautta (Scott 2000). Valintojen tekeminen varmasti edistää tunnetta autonomiasta, oman elämän hallinnasta ja sosiaalisesta osallistumisesta (Glendinning 2008, 459-461). Aina ei kuitenkaan ole itsestään selvää, että valinnanvapaus todella toteutuu niin, että ihmiset pystyvät valitsemaan itselleen parhaan palvelun (Greve 2009). Valintojen tekeminen edellyttää kykyä toimia kuluttajana eli märitellä tarpeet, hankkia tietoa ja vertailla vaihtoehtoja, valita palveluntuottaja ja vaihtaa se tarvittaessa, ja lopulta saada palvelun avulla täytettyä ne tarpeet, joita varten palvelu hankittiin (Newman \& Clarke 2009; Newman \& Tonkens 2011, 10-11).

Ajatus rationaalisen kuluttajan autonomisesta toiminnasta ja hyvinvointia parhaiten edistävien valintojen tekemisestä on ongelmallinen toimintakyvyltään heikompien vanhojen ihmisten kohdalla (Anttonen 2009). Palvelunkäyttäjän aktiivisuus, vastuullisuus ja osallistuminen vanhusten hoivassa eivät ole itsestään selviä (Kröger, Karisto \& Seppänen 2009, 12). Sosioekonominen tausta, fyysinen ja psyykkinen kunto, informaalin avun saatavuus ja lähiverkostojen tuki vaikuttavat kykyyn ja mahdollisuuksiin toimia valintojen tekijänä. Apua ja hoivaa tarvitsevat ihmiset tarvitsevat useimmiten apua myös palvelujen hankkimiseen (Van Aerschot 2014).

\section{Palveluseteli suomalaisissa kunnissa ja vanhustenpalveluissa}

Palveluseteliä on käytetty kokeilumuotoisesti sosiaalipalveluissa jo 1990-luvulla. Vuonna 
2004 palveluseteli vakinaistettiin sosiaalihuollon palveluihin ja vuonna 2009 lakia laajennettiin koskemaan kaikkia sosiaali- ja terveyspalveluja, paitsi kiireellistä ja tahdonvastaista hoitoa. (Laki sosiaali- ja terveydenhuollon palvelusetelistä 569/2009; Hakala \& Weckström 2011, 236; Kuusinen-James 2016, 76.) Palvelusetelilain ensimmäiseen pykälään on kirjattu tarkoitukseksi "lisätä asiakkaan ja potilaan valinnan mahdollisuuksia, parantaa palvelujen saatavuutta ja edistää kuntien sosiaali- ja terveystoimen sekä elinkeinotoimen ja yksityisten palvelujen tuottajien yhteistyötä."

Vaikka kuntien on jo vuosia ollut mahdollista käyttää palvelusetelejä, niiden käyttö ei ole levinnyt niin laajasti kuin voisi olettaa. Palveluseteli oli käytössä ainakin 127 kunnassa vuosina 2006-2007 (Volk \& Laukkanen 2007, 22) eli noin neljänneksessä sen hetkisistä Suomen kunnista. Lähes kaikki 127 kuntaa käyttivät palveluseteliä sosiaalipalveluihin (emt., 22). Palveluseteli on levinnyt hitaasti. Sitä on ollut vaikea integroida muihin sosiaalija terveydenhuollon järjestelmiin ja palvelusetelin käytöstä aiheutuvia taloudellisia vaikutuksia on ollut hankala arvioida (Hakala \& Weckström 2011, 245-249).

Palveluseteli oli vuonna 2012 käytössä noin kolmasosassa Suomen kunnista eli reilussa sadassa kunnassa tai kuntayhtymässä (Nemlander \& Sjöholm 2012), ja vuonna 2015 yli 120 kuntaa tai kuntayhtymää käytti palveluseteliä palveluiden järjestämiseen (Nemlander \& Sjöholm 2015). Palveluseteliä on käytetty selvästi eniten sosiaalipalveluissa, erityisesti vanhuksille suunnatuissa palveluissa kuten kotipalvelussa, kotipalveluiden tukipalveluissa ja omaishoidossa. Palvelusetelit ovat yleistyneet erityisesti tehostetussa palveluasumisessa. (Volk \& Laukkanen 2007; Nemlander \& Sjöholm 2012; Nemlander \& Sjöholm 2015.)

Palveluseteli on mahdollista ottaa käyttöön sellaisissa palveluissa, jotka kunta on velvollinen kokonaan tai osittain rahoittamaan. Palvelusetelin voi saada julkiseen palveluun oikeutettu kuntalainen palvelutarpeen arvioinnin jälkeen. Palvelutarpeen arviointi on sama huolimatta siitä, onko kunnassa käytössä palveluseteli vai ei. Palvelunkäyttäjä voi valita palvelusetelillä yksityisen yrityksen tai järjestön tuottamia palveluja siten, että palveluseteli kattaa niiden hinnan kokonaan tai osittain kunnan ennalta määrittämään arvoon asti. Kunnat voivat ottaa palvelusetelin käyttöön useissa palveluissa tai vain joissakin, ja setelin arvo voi olla kaikille sama tai riippua asiakkaan tuloista. Kunnat päättävät palvelusetelien myöntämisen kriteereistä ja niiden palveluntuottajien listaamisesta, joiden palveluihin seteliä voi käyttää. (Laki sosiaali- ja terveydenhuollon palvelusetelistä 569/2009, § 3-4; Kuusinen-James 2012, 39-40.) Näin kunnilla on varsin paljon palvelujärjestelmän valvontaan ja ohjaamiseen liittyvää määrittelyvaltaa, vaikka ne ottaisivatkin palvelusetelit käyttöön ja ohjaisivat palvelunkäyttäjiä asioimaan yksityisellä sektorilla.

Palveluseteli toimii vaihtoehtona kunnan tuottamille palveluille, mutta palvelunkäyttäjät eivät kuitenkaan ole pakotettuja ottamaan vastaan palveluseteliä. He voivat halutessaan pyytää kuntaa tarjoamaan palvelun muulla tavoin. Kunnat eivät myöskään ole velvoitettuja tarjoamaan palveluseteliä vaan palveluseteli otetaan kunnassa käyttöön palvelujärjestelmää koskevan poliittisen päätöksen myötä. (Zechner 2012; Karsio \& Anttonen 2013, 94-96). Hankkiessaan palveluja yksityiseltä palveluntuottajalta palveluseteliasiakkaat eivät ole sopimussuhteessa kuntaan vaan palveluntarjoajaan. Palvelusetelin käyttäjät ovat sekä sosiaalija terveydenhuollon lakien että kuluttajasuojalain alaisia. Mahdollisten ongelmien ratkaisu on kuluttajaoikeuden ja sopimusoikeuden säännösten ja oikeusperiaatteiden mukaista (Laki sosiaali- ja terveydenhuollon palvelusetelistä 569/2009, § 6; Aho 2012, 130; KuusinenJames \& Seppänen 2013, 317).

Volkin ja Laukkasen mukaan $(2007,24)$ kunnat ilmoittivat palvelusetelin käyttöönotolle tärkeimmiksi syiksi kasvavan palvelujen tarpeen, palvelutarjonnan sisällön monipuolistamisen, ja yrittäjyyden edistämisen kunnis- 
sa. Palveluseteli voi olla kuntien näkökulmasta myös vaihtoehto palvelutuotannon kilpailuttamiselle, jonka myötä kunta sitoutuisi ostamaan tietyt palvelut yhdeltä palveluntuottajalta määrätyn ajan. Kilpailuttaminen voi olla kunnalle hallinnollisesti työläs prosessi, ja laadun valvonta sopimuskauden aikana vaatii oman panoksensa. Laatuun tyytymättömän palveluseteliasiakkaan on sen sijaan mahdollista reagoida välittömästi esimerkiksi vaihtamalla palveluntuottajaa, jos vaihtoehtoja on tarjolla. Huonona puolena palvelusetelien käytössä on se, ettei palveluntuottajia voi velvoittaa tarjoamaan palveluja haja-asutusalueilla tai ottamaan vastaan kaikkia asiakkaita tai tehtäviä. Palvelunkäyttäjän maksettavaksi koituvia kuluja on lopulta vaikea ennustaa, sillä yritykset voivat nostaa hintojaan, asiakkaan palvelutarpeet voivat kasvaa, ja kustannukset voivat yllättäen tulla ennakoitua suuremmaksi. (Kuusinen-James 2012, 82.)

Suomalainen palvelusetelijärjestelmä on melko vaikeaselkoinen, ja paikallisen vaihtelun vuoksi on hankalaa linjata palvelusetelien käytön yleisimpiä piirteitä (Karsio \& Anttonen 2013). Suomalaisissa kunnissa on siis toteutettu lukuisia erilaisia paikallisia palvelusetelimalleja. Lisäksi eri palveluissa palvelusetelin käyttö muodostuu erilaiseksi. On eri asia ostaa palvelusetelillä esimerkiksi siivousta, jolloin palvelun tarve ja siihen vastaaminen on melko helppo määritellä, verrattuna palvelutalopaikkaan, johon liittyy kokonaisvaltainen hoivan tarve ja josta tulisi muodostua koti vuosiksi eteenpäin. Saadaksemme lisää tietoa siitä, miten palveluseteleitä Suomessa käytetään vanhusten palveluissa ja millaisena palvelujärjestelmän osana ne kunnissa toimivat, on tarkasteltava paikallisia käytäntöjä ja tapoja ymmärtää palveluseteli (Hakala \& Weckström 2011, 250). On tärkeä huomioida, että vaikka palveluseteli edustaa tietynlaista palvelujen järjestämisen mallia, sen paikalliset toteutukset ja tavoitteet eroavat toisistaan.

\section{Tutkimusasetelma}

Tutkimusaineistomme koostuu 27:n sosiaalija terveydenhuollon sekä vanhuspalveluiden johtajien ja viranhaltijoiden puolistrukturoiduista teemahaastattelusta (Francis \& Abel, 2014; Shaw, 2014). Ne on kerätty kuudesta erikokoisesta kunnasta, jotka sijaitsevat eri puolilla Suomea. Haastateltavat työskentelivät kuntaorganisaation eri tasoilla: suurin osa oli vanhuspalvelujen johtajia ja korkeimpien virkojen haltijat olivat sosiaali- ja terveysjohtajia. Kunnissa, joissa on käytössä tilaaja-tuottaja -malli, viranhaltijoita haastateltiin sekä tilaajaettä tuottajapuolella. Haastatteluissa kysyttiin palvelusetelin käytöstä ja siihen liittyvistä näkemyksistä osana laajempaa vanhuspalvelujen järjestämistä koskevaa tutkimusta. Haastattelut kerättiin osana Kelan rahoittamaa hanketta "Kuka tuottaa, kuka maksaa ja kuka hyötyy? Palvelumarkkinoiden paikallinen hallinta ja vanhushoivan uudet käytännöt”. Haastatteluista 22:ssa valinnanvapaudesta keskusteltiin palvelusetelin näkökulmasta. Loput viisi haastattelua eivät sisältäneet keskustelua palvelusetelistä ja ne rajautuivat pois lopullisesta analyysista.

Haastattelujen mukaan palveluseteliä käytettiin tutkimuskunnissa ikääntyneiden omaishoidossa, kotihoidossa ja sen tukipalvelussa, sekä tehostetussa palveluasumisessa. Tehostetussa palveluasumisessa palveluseteli oli käytössä viidessä tutkimuskunnassa, kotihoidossa ja sen tukipalveluissa viidessä kunnassa, ja omaishoidon tukipalveluissa myös viidessä kunnassa. Pisimpään palveluseteleitä on käytetty omaishoidon tukena tarjoamalla setelien avulla omaishoitajille mahdollisuutta järjestää oman vapaansa ajaksi hoitoa hoivan tarvitsijalle tai muuta tukea arkeen, kuten siivouspalvelua (ks. Zechner 2017 tässä teemanumerossa). Kotihoidossa ja sen tukipalveluissa palveluseteleitä käytettiin eri tavoin. Palvelusetelin määrästä tai kattavuudesta eri palveluissa ei erikseen kysytty haastatteluissa, mutta haastateltavat toivat näitä asioita esiin. Setelien mää- 
rät vaihtelivat merkittävästi. Esimerkiksi eräässä alle 100000 asukkaan kaupungissa tehostetussa palveluasumisessa oli haastatteluhetkellä 10 palveluseteliasiakasta ja toisessa isommassa kaupungissa niitä oli kymmenkertainen määrä.

Tutkimuksen analyysimenetelmiä ovat teemoittelu (Braun \& Clarke, 2006; Chon, 2013; Voisin \& Bird, 2012) ja sisällönanalyysi (Tuomi \& Sarajärvi 2002). Aineiston analyysia on ohjannut tavoite ymmärtää millaisena palveluiden järjestämisen tapana vanhuspalveluista vastaavat viranhaltijat ymmärtävät palvelusetelin ja millaisia perusteluita palvelusetelin käyttöönotolle on asetettu. Kuten jo totesimme, suomalainen palvelusetelijärjestelmä on ainutlaatuinen ja antaa kunnille vapauden ottaa palvelusetelin käyttöön hyvin erilaisin tavoin. Siksi palvelusetelin tutkiminen paikallisesti on ollut ainoa mahdollisuus saada tarkempaa tietoa siitä, mitä tarkoitusperiä palvelusetelit kunnissa palvelevat.

Asiantuntijahaastatteluissa keskeistä on tavoittaa asiantuntijoiden hallussa oleva tieto tutkittavasta ilmiöstä (Bogner, Littig \& Menz 2009; Alastalo, Åkerman \& Vaittinen 2017). Analyysimme kohdistui viranhaltijoiden näkemyksiin palvelusetelistä ja sen käyttötavoista. Tutkimuksen tulokset eivät kerro suoraan palvelusetelin paikallisista käytännöistä, vaan aineisto on näyte kuuden kunnan avainhenkilöiden näkemyksistä palvelusetelistä. Haastatteluihin osallistuneet viranhaltijat kuvaavat palveluseteliä omasta näkökulmastaan ja kenties muistaen tai painottaen haastatteluhetkellä joitakin puolia enemmän kuin toisia. Asiantuntijahaastattelut ovat erityinen laadullinen aineisto, jossa keskeisesti palvelujen järjestämiseen vaikuttavat viranhaltijat kuvaavat palveluseteliä haluamallaan ja tärkeäksi katsomallaan tavalla.

Tutkimuskysymyksemme ovat, millaiseksi vanhuspalvelujen järjestämisen välineeksi palveluseteli kunnissa ymmärretään, sekä miten sen käyttöönottoa perustellaan suomalaisissa kunnissa. Käytännössä analyysi toteutettiin rajaamalla aineistosta laajat aineisto-otteet, joissa käsiteltiin palveluseteliä ja koodaamalla kaikki palveluseteliin liittyvät kommentit ja lausumat omiksi aineistoyksiköikseen. Seuraavassa vaiheessa aineistosta etsittiin palvelusetelin perusteluja, tavoitteita, käyttöä, palvelusetelijärjestelmän suunnittelua ja implementointia käsitelleet aineisto-otteet. Käytimme aineiston analyysin luotettavuuden vahvistamiseksi tutkijatriangulaatiota (Tuomi \& Sarajärvi 2002). Molemmat tutkijat ryhmittelivät aineistootteita useissa vaiheissa erilaisten teemojen ja näkökulmien alle. Lopulta rajasimme analyysin erityisesti neljään sellaiseen teemaan, jotka toistuivat useammissa tutkimuskunnissa ja -haastatteluissa ja jotka vastasivat tutkimuskysymyksiimme palvelusetelin perusteluista ja palvelujen järjestämiseen liittyvistä näkemyksistä: 1) Palveluseteli asiakkaiden ja palvelutuotannon ohjailun sekä kustannussäästöjen välineenä; 2) Palveluseteli ja paikalliset palvelumarkkinat; 3) Palvelusetelin soveltuvuus vanhoille asiakkaille; ja 4) Palveluseteli tasa-arvon ja eriarvoisuuden näkökulmista.

Palveluseteli ohjailun ja kustannussäästöjen välineenä

Palveluseteli ymmärretään useissa kunnissa työkaluna, jolla on mahdollista ohjata palvelujen tarvitsijoita kunnallisista palveluista yksityisten palvelujen käyttäjiksi silloin, kun siihen on tarvetta. Yhdessä tutkimuskunnassa palveluseteleitä tarjottiin asiakkaille vain, kun kunnan itse tuottamat palvelut eivät riittäneet vastaamaan palveluntarpeeseen. Tällöin asiakkaalle tarjottiin mahdollisuutta valita palvelusetelillä yksityinen palveluntuottaja sen sijaan, että vanhus joutuisi jonottamaan julkisen puolen palvelua. Jos kuitenkin kunnan tuottamien palvelujen piirissä oli tilaa, palveluseteliä ei asiakkaalle tarjottu. 
$V^{1}$ : Joo se lähtee liikkeelle että kun [...] vanbukselle syntyy oikeus tähän ympärivuorokautiseen [hoitoon] niin, ensimmäinen vaibe on se, että katsotaan onko meillä omaa paikkaa tarjolla. Jos meillä ei ole omaa paikkaa tarjolla ja bän sen välttämättä tarvitsee, niin tarjotaan mahdollisuutta ostaa palvelu palvelusetelillä.

K: Mitäs jos on oma paikka, niin tarjotaanko vaibtoebdoksi..?

$V$ : Ei, ei voi tarjota. Ei pysty tarjoamaan. (Haastattelu 21, kunta $\mathrm{E}^{2}$ )

Haastateltavan mukaan palveluseteliä ei ole mahdollista tarjota asiakkaille, mikäli palvelupaikka löytyy julkiselta puolelta. Vaikka tällainen palvelusetelien käyttäminen julkisia palveluja täydentävänä ja paikkaavana välineenä on julkilausuttu periaate vain yhdessä kunnassa, useat haastateltavat nostivat esiin huolen siitä, että kunnan omat palvelut voivat jäädä alikäytölle, mikäli palveluseteliä tarjotaan kaikille asiakkaille vanhuspalveluissa ja asiakkaat valitsevat ennemmin yksityisen kuin julkisen palvelun. Kunnille aiheutuu taloudellinen riski, jos rahaa kanavoituu palvelusetelien kautta yksityisille palveluntuottajille eikä kunnan omiin palveluihin riitä asiakkaita, mutta ylläpitokustannukset ja työntekijöiden palkat juoksevat (Palola 2011, 292; Kuusinen-James 2016, 187-188). Tämän tutkimuksen haastatteluista ei käy ilmi, miksi tätä ei nähty ongelmaksi osassa kunnista ja niissä oli päädytty tarjoamaan palveluseteliä laajasti vanhuksille.

Haastateltavamme kertoivat palveluseteliä käytettävän ulkoistamisen sijaan välineenä, jolla voi ohjailla palveluntuotantoa ja -tarjontaa ilman raskasta hallinnollista työtä. Kunta ei kuitenkaan voi jättää palvelusetelimarkkinoita täysin oman onnensa nojaan. Viranhaltijoiden voi olla tarpeen seurata niitä tiiviisti, sillä kunnan hallinto on joka tapauksessa vastuussa siitä,

V tarkoittaa vastaajaa ja K kysyjää aineisto-otteissa.

2 Aineisto-otteissa haastateltavat ovat numeroitu 1-22 ja kunnat listattu A-F. että kuntalaiset saavat hyvinvointinsa kannalta välttämättömiä palveluja. Kunnan on myös järkevää varmistaa hintojen pysyminen kohtuullisella tasolla. Yksi viranhaltija kuvaili haastattelussa palvelusetelien käytön olevan monella tavalla joustavaa kunnan näkökulmasta, mutta toisaalta kertoi myös, että palvelumarkkinoita pitää seurata jatkuvasti.

Se on ainakin helpompaa [...] Se on hallinnollisesti huomattavasti helpompaa, ja siellä tosiaan kaikki, jotka täyttää palvelusetelin kriteerit niin, kaikki pääsee tarjoon palveluitaan kuntalaisille. Et meiänhän rooli on tietysti se, että me osataan laittaa se palvelusetelin arvo riittäväks. Et jos se on liian korkee, niin sillonhan markkinoilla nousee kaikki binnat. Mut sitte taas jos se on liian matala, niin sillon ehkä pienituloisimmat ei välttämättä käytä sitä seteliä. [...] että ei siinä hanskoja tiskiin voi lyödä vaan et kyl sun pitää koko ajan seurata sitä markkinaa et ketä siel on, minkälaist palvelua siel on tarjolla ja millä binnalla. (Haastattelu 15, kunta B)

Palvelusetelien antaminen asiakkaille palvelujen sijaan tuo kunnille kysynnän ohjailun lisäksi mahdollisuuden kustannussäästöihin, sillä asiakas maksaa palveluseteliä käyttäessään palvelusta omavastuuosuuden, jolle ei laissa ole asetettu kattoa (Fredriksson, Junnila \& Tynkkynen 2012, 95-96, 104; Lehto \& Tynkkynen 2013, 613; Kuusinen-James 2016). Joissakin tutkimukseemme osallistuneista kunnista oli seurattu tarkasti palvelusetelien taloudellisia vaikutuksia ja laskettu niiden tuovan huomattaviakin säästöjä.

Ja, siit, se, sit se on tietysti siinä on yks elementti, tää on, jonka nyt voi sanoa suoraan palveluseteliinbän on sisään synnytetty myös säästöelementti. (Haastattelu 4, kunta D)

Tällä hetkellä meillä on 105 tehostetun palveluasumisen palveluseteliä käytössä ja me ollaan saatu sillä kaupungille säästöo [...] se 
on merkittävä [...] sä voisit kysyä jos sä haluat sen luvun iban (säbköpostiosoite poistettu) [...] en mä saa sitä nyt päästäni ulos. (Haastattelu 13, kunta B)

Säästöjä käsittelevässä puheessa on huomionarvoista, että säästöjä pohditaan kunnan eikä asiakkaan näkökulmasta. Yllä olevassa sitaatissa haastateltava ei ota esiin sitä, että kunnalle saatu säästö tarkoittaa asiakkaiden maksamien osuuksien kasvamista ja muutosta siihen, miten eri asiakasryhmät voivat palveluja käyttää. Pienituloisten asiakkaiden kohdalla palvelumaksujen kasvamisessa on kyse erittäin merkittävistä muutoksista.

Palveluseteli ja paikalliset palvelumarkkinat

Jotta palveluseteli toimisi asiakkaiden valinnanmahdollisuuksia lisäävänä välineenä, tarjolla pitää olla riittävä määrä varteenotettavia palveluntuottajia. Sellaisissa kunnissa, joissa palvelumarkkinoita ei ole, palvelusetelien tarjoaminen julkisten palvelujen asiakkaille ei ole todellinen valinnanmahdollisuuksia edistävä vaihtoehto (Zechner 2012, 49; KuusinenJames 2016, 51, 188). Tutkimukseemme osallistuneista paikoista isommissa kaupungeissa oli riittävästi palveluntuottajia, jotta asiakkaat saattoivat tehdä valintoja esimerkiksi tehostetun palveluasumisen palveluissa. Sellaisissa kunnissa, joissa on laajoja maaseutualueita, palveluntarjonta saattoi käytännössä kattaa vain keskusta-alueen. Tällöin palveluseteleiden käyttäjille on olemassa markkinat vain siinä tapauksessa, että he asuvat kohtuullisen lähellä keskustaa tai ovat valmiita sinne muuttamaan. Vapaata valintaa voi rajoittaa palvelujentarjonnan puuttumisen lisäksi myös se, että asiakkaalle ei esimerkiksi ole tilaa siinä palvelupaikassa, johon hän haluaisi. Nämä rajoitteet asettavat palvelusetelijärjestelmän tehokkuuden ja toimivuuden kyseenalaisiksi. [m]utta palvelusetelibän edellyttäis semmosta tilannetta, että kun me annetaan palveluseteli esimerkiks ikäibmiselle tai bänen omaiselleen ja hänelle, että vois oikeesti kävellä ympäri kaupungin palvelutaloja, ja valita, et hei, mä tykkään tosta, ja sitten ne veis sen palvelusetelin sinne ja niille järjestyis sieltä paikka. Mut meilläbän ei oo vapaita paikkoja. (Haastattelu 1, kunta A)

Ihanteena haastateltava näkee tilanteen, jossa asiakkailla olisi riittävä määrä palveluntuottajia, joista valita. Haastateltavan edustamassa kunnassa ylimääräistä palveluntarjontaa ei ollut, vaan kunta osti kaiken markkinoilla olevan palvelun.

Yhdessä tutkimuskunnista palveluseteli oli päätetty laajentaa ainoaksi tavaksi palvelujen ulkoistamisessa eli yhden vanhuspalvelun osalta kaikki yksityiseltä hankittavat palvelut oli päätetty järjestää palvelusetelillä.

\section{Kyllä nyt on ajatus, että kun se keskitetään palvelusetelituotannon kautta toteutuvaks niin, asiakasmarkkinat objaavat hintoja. Sillon ku se on kokonaan käytössä, niinbän sen täytys toimia. Ja biukan sitä jo näkyy. Et nää on ongelmallisia joillaki alueilla. On seka- järjestelmiä, on puitesopimuksia ja erilaisia sopimuksia ja sitte on palveluseteli niin eibän se objaa kunnolla sitä palvelutuotantoa min- kään ybtenäisen rybmän kautta. Kyllä palve- luseteli on ebdottomasti [...] erittäin byvä jär- jestelmä. (Haastattelu 21, kunta E)}

Kunnassa palvelusetelin laajentamista perusteltiin sillä, että se toimii parhaiten, jos markkinoiden annetaan mahdollisimman vapaasti kehittyä. Ideaalina haastateltava näki tilanteen, jossa markkinamekanismien annetaan hoitaa hintojen ja tarjonnan kehitys. Markkinat kuitenkin vaihtelevat muutoinkin kuin kuntien käyttämien hankintamenetelmien perusteella eri kuntien ja alueiden välillä, sekä kuntien sisällä eri palvelutyyppien välillä. 
[t]ällä alueella on tukipalvelujen markkinoita, siivousta, ateriapalveluita ja tämän tyyppistä, koska niit ei tarjota julkisesti [...]. Et sillä alueella mun mielestä täällä on palvelumarkkinoita, et asiakkaat pysyy siltä osin valitsemaan. Muitten palvelujen osalta niin, aika paljon tukeudutaan vielä kuitenkin julkisen kautta järjestettyyn palveluun. Jossain määrin itse maksaviakin hakeutuu suoraan [yksityisten palvelujen asiakkaiksi], mutta väbäsemmässä määrin, ja nyt mä pubun tästä keskusalueesta, sit kun [...] mennään noibin kyliin ja niin edelleen niin, en mä tiedä voidaanko siellä pubua palvelumarkkinoista.. (Haastattelu 7, kunta F)

Haastateltava tuo sitaatissa esiin, että valinnanmahdollisuuksia on vain joissakin palveluissa ja joissakin osissa kuntaa. Vaikka asiakkaat haluaisivatkin käyttää yksityisiä palveluja tai kunta haluaisi tarjota valinnanvapautta, se ei välttämättä ole mahdollista. Useimmissa tutkimuskunnissa ajateltiin, että markkinaehtoiset palvelut vastasivat kuntien tarpeisiin parhaiten juuri tukipalveluissa ja kevyemmissä palvelumuodoissa. Tukipalveluita tuottavat yritykset ovat tavallisesti pieniä (Lith 2013), ja niiden perustaminen on huomattavasti helpompaa kuin esimerkiksi kotipalveluyrityksen tai ympärivuorokautista hoivaa tarjoavan yrityksen. Toisaalta Suomessa ympärivuorokautista hoivaa tarjoavat yritykset tuottavat merkittävän osan julkisesti kustannetuista palveluista, joten myös näissä palveluissa on markkinavaihtoehtoja (Karsio \& Anttonen 2013).

Palvelusetelin soveltuvuus vanhoille ihmisille

Koska palveluseteli on väline, jonka tarkoituksena on valintojen tekemisen mahdollistaminen, on tärkeää esittää kysymys siitä, miten hyvin hoivaa tarvitsevat vanhat ihmiset pystyvät tekemään palveluja koskevia valintoja ja hankkimaan siihen tarvittavaa tietoa (KuusinenJames 2012; Zechner 2012, 53; Kuusinen-
James \& Seppänen 2013). Palveluja tarvitsevien ikäihmisten fyysinen ja psyykkinen terveys ja toimintakyky vaihtelevat. Kunnissa tarjolla olevien yksityisten palveluntuottajien määrä vaihtelee, ja siten valintoja tehdään hyvin erilaisissa tilanteissa. Yhdessä kunnassa apua tarvitsevan vanhuksen omainen saattaa tuntea esimerkiksi kaikki siivouspalvelua tarjoavat palvelusetelituottajat, joten vanhuksen tarpeisiin sopiva palvelu voi olla helppo valita.

[s]anotaan siivouspalvelussa se toimii ihan byvin. Koska se on kuitenkin semmonen selkeä alue mistä asiakkaalla on aika äkkiä näkemys et onko hyvä vai ei. Ja sitä he pystyy vielä jotenki hanskaamaan ja on palveluntuottajia. (Haastattelu 19, kunta C)

Toisessa kunnassa huonokuntoinen vanhus voi joutua itse valitsemaan kymmenien palveluntuottajien joukosta, jolloin sopivimman palvelun löytyminen voi olla hakuammuntaa. Yhdessä tutkimuskunnassa käytäntönä oli, että asiakas valitsee yksityisten palveluntuottajien listasta kolme yritystä, joille kunnan työntekijä laskee lopullisen hinnan, siis sen, joka jää asiakkaan maksettavaksi omavastuuosuudeksi.

[a]siakas itse valitsee sieltä rekisteristä ja sitten pyytää laskemaan et mitä se maksaa [...] ja sit me ollaan suostuttu kolme arvoa sieltä hänelle laskemaan ja sit hän valitsee sieltä haluamansa yrittäjän. (Haastattelu 6, kunta D)

Käytäntö helpottaa asiakkaan valintaprosessia, mutta kyseenalaista on, miten monipuolisesti valintaa tekevä vanhus on lopulta kykenevä arvioimaan eri palveluntuottajien eroja. Pelkän hinnan perusteella tehtävä valinta ei aina ole paras mahdollinen, sillä myös palvelun sisältö saattaa vaihdella tai palveluntuottajilla voi olla erityisiä ehtoja. Vanhukset ovat erityinen palveluntarvitsijoiden ryhmä, sillä heidän keskuudessaan muistisairaudet ja muut toimintakykyä rajoittavat sairaudet ovat yleisempiä kuin 
muilla. Jos asiakkaat eivät kykene tekemään perusteltuja valintoja palveluntuottajien välillä, ei lopputulos ole asiakkaan, palvelujärjestelmän tai markkinoiden näkökulmasta paras mahdollinen. Valinnat eivät tällöin ohjaa markkinoita oletetulla tavalla, sillä asiakkaalle parhaiten soveltuva palveluntuottaja ei välttämättä tule valituksi.

Et tä̈̈ palveluseteliajatus perustuu siiben että, asiakas on se joka kilpailuttaa. Jos me ajatellaan nyt meidän asumispalvelujonossa olevia asiakkaita, ne ei kilpailuta ybtään mitään, se on ihan selvä. He on ympärivuorokautisen hoivan tarpeessa, heillä ei oo kykyä läbtee näitten asioitten perään edes soittelemaan, saati muuten sitten arvioida asioita. (Haastattelu 19, kunta C)

Sitaatissa nostetaan esiin näkökulma, jota eräs haastateltava painotti: vanhusten kohdalla on turhaa puhua valintojen tekemisestä, jos asiakkaat eivät ole toimintakykynsä puolesta kykeneviä toimimaan kuluttajina. Tällaisissa tilanteissa voidaan olettaa, että asiakkaan läheinen tai omainen tekee valintoja vanhuksen puolesta eli toimii epäsuorana tai sijaiskuluttajana (proxyconsumer) (esim. Vabø 2006). Silloin ei kuitenkaan enää pitäisi puhua asiakkaan valinnanvapaudesta, kun valinnan vanhuksen puolesta tekee omainen tai läheinen. On myös tärkeää kysyä, tekevätkö omaiset ja läheiset aina parhaita mahdollisia valintoja vanhuksen puolesta. Entä kuka tekee valinnat niiden puolesta, joilla ei ole omaisia tai läheisiä huolehtimassa heidän palveluistaan?

Joissakin kunnissa luotetaan palvelusetelin toimivuuteen ja vanhusten oletetaan olevan toimintakyvyltään kykeneviä tekemään perusteluja valintoja. Lisäksi vanhusten uskotaan pystyvän myös vaihtamaan palveluntuottajaa ollessaan tyytymättömiä saamaansa palveluun. Hirschmania (1970) mukaillen palveluseteliä käyttävän vanhuksen oletetaan kykenevän valitsemaan (choice), vaatimaan (voice) ja hylkäämään (exit) yksityisen palveluntuottajan.
Palveluseteli hyvin harkittuna, buolellisesti käyttöonotettuna antaa kuntalaiselle mahdollisunksia. Se on tuonu ybden uuden ilmiön siinä, että meillähän palvelukodin vaihtaminen on ollu pitkä prosessi. Palveluseteli-ibminen voi ottaa setelinsä ja lähteä. Ja he myös tekevät sitä. Heidän ei tarvi kuin kaks kertaa sanoa, että jos ei parane läbden ja kolmannella kertaa sanoo, että otanpas rahani ja läbden, näkemiin. Ja se jää palvelutuottajan tappioksi. Tää on ihan mielenkiintonen ilmiö ja tätä on, kyllä tämä panee palvelutuottajat varpailleen, jatkossa. (Haastattelu 13, kunta B)

Tulevaisuudessa saamme todennäköisesti lisää tietoa siitä, miten usein palveluasumisen kaltaista apua tarvitsevat vanhat ihmiset todellisuudessa vaihtavat palveluntarjoajaa, eli muuttavat palvelutalosta toiseen. Ikääntyneille ihmisille, joilla on paljon avun ja hoivan tarpeita, muuttaminen ei ole yksinkertaista. Vaihtoehtojen selvittäminen ja niiden vertailu on vaativa ja aikaa vievä prosessi. Siksi aito valinnanvapauden toteutuminen ja asiakkaiden mahdollisuus äänestää jaloillaan voi sopia huonosti palveluasumisen kaltaisiin palveluihin (Rostgaard 2006). Tutkimustietoa palveluntuottajan vaihtamisesta vanhuspalveluissa on jo Ruotsista, missä vanhusten kotipalvelut on järjestetty asiakkaan vapaalla valinnalla (Vamstad 2015). Tutkimuksen mukaan vanhukset eivät vaihtaneet palveluntuottajaa lähes lainkaan, ja osa heistä ei edes ollut tietoisia siitä, että he olivat tehneet valinnan palveluntuottajien välillä.

Palveluseteli tasa-arvon ja eriarvoisuuden näkökulmista

Osassa tutkimuskuntia palveluseteliä tarjottiin kaikille julkisiin palveluihin oikeutetuille vanhuksille. Asiakkaat saattoivat näissä kunnissa valita haluavatko vastaanottaa palvelusetelin vai saada palvelunsa julkiselta sektorilta tai muutoin kunnan osoittamalla tavalla. Vastaanottaessaan palvelusetelin asiakkaat ohjautuvat omien tai omaistensa valintojen perus- 
teella joko yksityisten yrittäjien tai kolmannen sektorin toimijoiden asiakkaiksi.

Joissakin kunnissa palveluseteliä tarjottiin valinnanvapauden lisäämiseen vain niille asiakkaille, joilla yksityisen palvelun hankkimiseen ajatellaan olevan varaa. Kunnan viranhaltija tekee tällaisissa tapauksissa arvion asiakkaan taloudellisesti tilanteesta ja päättää palvelusetelin tarjoamisesta.

K: Eli kaikilla on se mahollisuus. Onks se semmonen mitä sä tarjoot? Vai [...] mitä ibmisten pitää osata pyytää?

V: Kyllä mä saatan ottaa pubeeksiki sen, ehdottaa ja sanoa että tämmönenkin on olemassa mutta kun se on siitä huolimatta aika kallis palvelu, niin ibmiset ei oikein innostu siitä. K: Mut sä et tarjoo sitä ihan kaikille kuitenkaan?

$V:$ En. Jos heti kuulostaa että rahasta on tiukkaa, niin ei kannata edes ruveta pubumaan tällasesta. (Haastattelu 3, kunta A)

Kyseisessä kunnassa palvelusetelipaikka tuli selvästi kalliimmaksi asiakkaalle kuin kunnan oma palvelupaikka. Palveluseteliä tarjoava kunnan työntekijä arvioi ensisijaisesti asiakkaan taloudellista mahdollisuutta ottaa palveluseteli vastaan, ennen kuin edes harkitsee sen esille ottamista. Aikaisemman tutkimuksen mukaan kunnan työntekijät tarjoavat palveluseteliä asiakkaan kokonaistilanteen arvioinnin perusteella (Kuusinen-James 2016). Huomioon otettavat seikat koskevat asiakkaan toimintakykyä, palvelutarpeiden säännönmukaisuutta, etuuksien määrää, omaisten roolia hoivan antamisessa, hoidon tarpeen tasoa ja palvelumaksujen lopullista tasoa (emt., 114; myös Zechner 2012, 53).

Kun kunta määrittelee, kenelle palveluseteliä tarjotaan ja millä ehdoilla, tehdään merkittäviä linjavetoja palveluja tarvitsevien vanhusten eriarvoisuuden ja tasa-arvoisuuden suhteen. Sekin on linjanveto, että tasa-arvoisuuden näkökulmaa ei huomioida tai että yhdenvertaisuus on vähemmän tärkeä näkökulma kuin valinnanvapaus.
Siis palveluseteli, mä en nää sitä tämmösenä että se on tasa-arvoa lisä̈̈vä. Mut se on valinnanvapautta lisäävä. [...] Se on kuitenki sillain tasa-arvosta, jos sitä nyt läbtee taas niin että hyvinvointiybteiskunta on kaikille kuntalaisille, niin valinnanvapautta baluavalle, kohtuullisen rahapussin omaavalle, se on kunnan kädenojennus et saat ton verran kunnalta ja paa omas likoon. Mä oon byväksyny tän tosiasian. Mä voin ihan hyvin edistää palveluseteleitä, mutta mä haluan koko ajan pitää tämän keskustelun yllä, että se ei edistä tasa-arvoa, mut se lisää valinnanvapautta. Ja sen valinnanvapauden riskit meidän pitää kuntalaisille selvittää. (Haastattelu 13 , kunta B)

Haastateltava kertoo, että palveluseteli on kunnassa selvästi suunnattu hyvätuloisille. Kyse on valinnasta, sillä palvelusetelijärjestelmä voidaan rakentaa myös tasa-arvoiseksi, jos niin halutaan. Palvelusetelin käyttämisen ei tarvitse tarkoittaa asiakkaan maksaman osuuden kasvamista, koska palvelusetelin omavastuuosuudelle voidaan määrittää maksukatto. Suomalaisissa kunnissa maksukaton käyttö on kuitenkin ollut harvinaista (Nemlander \& Sjöholm 2015).

Tutkimuksessamme oli mukana joitakin kuntia, joissa palvelusetelijärjestelmä on haluttu tehdä sellaiseksi, että valinnanmahdollisuuksia voidaan tarjota kaikille.

Siis joo, ne on tehty tulosidonnaisiksi [...] että se on aidosti mahdollisuus kaikille, että se ei ole vaan hyväosasten [...] vaan pienitulonenkin vanhus voi sen saada. (Haastattelu 4, kunta D)

Ja hyvinki paljo viime vuonna käytettiin koska meillä ei ollu vastata tarpeeseen. Mut meillä on kyllä ens vuoden alusta aivan samantasosia paikkoja [...]. Ensi vuoden alusta meillä on asiakkaan näkökulmasta taloudellisesti ihan ybdenvertainen tilanne, että hakeeko bän sen palvelusetelillä vai onko bän meidän järjestelmässä. (Haastattelu 21, kunta E) 
Haastatteluaineistomme osoittaa, että kunnissa ollaan hyvin tietoisia siitä, että palvelusetelijärjestelmä ja sen tarjoama mahdollisuus rajattuihin valintoihin voidaan rakentaa kaikkien vanhusten saataville tuloista riippumatta tai se voidaan luoda hyvätuloisille tarkoitetuksi kannustimeksi yksityisten palvelujen käyttöön. Palveluseteleiden suhteen tehdään tietoisia rajauksia ja päätöksiä, joilla rakennetaan järjestelmää halutun laiseksi.

\section{Johtopäätökset}

Tutkimuksessamme mukana olleissa kunnissa on erilaisia näkemyksiä siitä, millainen palvelujen järjestämisen väline palveluseteli on. Palveluseteleitä myönnetään ja käytetään myös hyvin erilaisin tavoin. Tutkimushaastattelumme osoittavat, että viranhaltijoilla on joissakin kunnissa merkittävä rooli sen määrittelyssä, keille palveluseteleitä käytännössä tarjotaan ja millä ehdoilla. Tutkimuksemme valottaa palvelusetelikäytäntöjen taustalla vaikuttavia näkemyksiä ja ymmärryksiä toimivista palvelujen järjestämisen tavoista ja periaatteista.

Tässä artikkelissa tarkastelimme ensinnäkin palveluseteliä asiakkaiden ja palveluntuotannon ohjailun sekä kustannussäästöjen välineenä. Palveluseteli tarjoaa kunnille mahdollisuuden ohjata asiakkaita julkisista palveluista yksityisiin ja hallita sitä kautta julkisten palvelujen asiakasmääriä. Palveluseteli toimii myös välineenä siirtää kustannuksia kunnalta palvelunkäyttäjille, sillä asiakkaat maksavat useimmiten palvelusta aikaisempaa suuremman osuuden itse.

Toiseksi tarkastelimme palveluseteliä paikallisten markkinoiden näkökulmasta. Kuntien viranhaltijoiden näkemykset paikallisten palvelumarkkinoiden toimivuudesta ja laajuudesta vaihtelivat. Yhtäältä uskottiin, että paikalliset palvelumarkkinat ovat hyvä ja toimiva tapa vastata palveluiden tarpeeseen. Toisaalta osassa kuntia yksityisten yritysten varassa toimivia palvelumarkkinoita ei nähty realistisena vaihto- ehtona. Palveluseteliin ja valinnanvapauteen liittyy perustavanlaatuisia ongelmia erityisesti harvaan asutuilla seuduilla. Palvelumarkkinoita syntyy vain sellaisille alueille, joilla on tarpeeksi kysyntää ja siksi valinnanvapaus on mahdollista vain alueilla, joilla yksityiset palveluntuottajat näkevät mahdollisuuden menestyä.

Kolmanneksi tarkastelimme sitä, miten palveluseteli soveltuu vanhusten palveluihin. Järkevien ja perusteltujen valintojen tekeminen ei ole mahdollista silloin, kun palvelunkäyttäjä on kovin huonokuntoinen, esimerkiksi vaikeasti muistisairas. Sosiaali- ja terveyspalveluissa on paljon tilanteita, joissa asiakas ei tarkasti tiedä, mitä hän tarvitsee tai mikä hänelle on parasta. Silloin palveluja järjestävillä viranhaltijoilla tai palveluntarvitsijan omaisilla voi olla merkittävä rooli palvelujen järjestämisessä ja valintojen tekemisessä. Asiakkaan valinnanvapaus on tällöin muista riippuvaista. Lisäksi on tärkeää huomioida, että kaikilla ei ole omaisia, jotka voisivat auttaa, eivätkä kaikki omaiset tee läheistensä kannalta parhaita mahdollisia valintoja.

Neljäs näkökulmamme koskee tasa-arvoa ja eriarvoisuutta. Palveluseteli voi olla tasaarvoinen tapa lisätä valinnanvapautta, jos kaikille asiakkaille annetaan mahdollisuus käyttää palveluseteliä, se määritellään tulosidonnaiseksi ja omavastuuosuudelle määritetään maksukatto. Aikaisemman pääkaupunkiseudulla tehdyn tutkimuksen perusteella tiedetään, että varakkaat ihmiset päätyvät palvelusetelin käyttäjiksi huomattavasti useammin kuin vähävaraiset (Linnosmaa, Seppälä, Klavus \& Oksanen 2012, 23, 39). Tutkimuksemme tukee tätä tulosta osoittamalla, että joissakin kunnissa palveluseteliä tarjottiin vain niille, joilla katsotaan olevan varaa maksaa itse osa palvelun kustannuksista. Palvelusetelin saajien valikoiminen tulojen tai varallisuuden perusteella on omiaan eriyttämään palveluja hyvätuloisten käyttämiin yksityisiin palveluihin ja pienituloisten käyttämiin julkisiin palveluihin. Tällaista hyvinvointipalvelujen eriytymistä on tutkittu aikaisemmin (esim. Kvist \& Greve 2011). 
Meneillään olevassa SOTE-uudistuksessa on korostettu valinnanvapauden lisäämistä yhtenä uudistuksen päätavoitteena. Monet asiantuntijat ovat kritisoineet uudistuksessa nimenomaan niitä tapoja, joilla valinnanvapautta on suunniteltu toteutettavan. Huolena on, että suuryritykset valtaavat markkinat ja valinnanvapaus mahdollistuu vain hyväkuntoisille ja riittävät taloudelliset ja sosiaaliset resurssit omaaville ihmisille. Moniongelmaiset ja heikoimmassa asemassa olevat ihmiset eivät pysty valinnanvapauttaan käyttämään (esim. Hoppania ym. 2016.)

SOTE-uudistuksessa vanhusten valinnanvapautta kaavaillaan lisättävän asiakassetelin ja henkilökohtaisen budjetin avulla (HE 47/ 2017). Tutkimuksemme tulokset ovat olennaisia uudistuksen kannalta. Ensinnäkin, jos uudistuksessa tavoitellaan yhdenvertaisuutta ja valinnanvapautta kaikille vanhoille ihmisille, on ensisijaista varmistaa, että palveluseteliä, asiakasseteliä tai henkilökohtaista budjettia ei käytetä vain julkisen sektorin kustannusten hillitsemiseen laskemalla palveluista korvattavaa summaa ja sitä kautta myös laskemalla tarjottavien palveluiden tasoa tai rajoittamalla niiden saatavuutta muille kuin niille, jotka maksavat osan itse. Valinnanvapautta lisäävät välineet eivät saisi johtaa kustannusten siirtämiseen vanhoille ihmisille itselleen, koska silloin vaarannetaan ihmisten tasa-arvoinen pääsy palvelujen piiriin.

Jotta valinnanvapaus ei johda alueelliseen eriarvoistumiseen, julkisen sektorin pitäisi huolehtia toimivista markkinoista koko Suomessa. Osittain tilanne saattaa parantua nyt kaavaillun uudistuksen myötä, jos vastuu palveluiden järjestämisestä siirretään kunnilta 18:1le maakunnalle. Nykyinen, paikoittain hyvin eriarvoinen järjestelmä on osaltaan seurausta Suomen satojen kuntien erilaisista palvelusetelikäytännöistä (vrt. Junnila, Hietapakka \& Whellams 2016). Valinnanvapauden soveltu- vuutta eniten apua tarvitseville asiakasryhmille, kuten vanhuksille, täytyy kuitenkin harkita tarkoin. On kyseenalaista puhua valinnanvapaudesta sellaisten vanhusten kohdalla, jotka eivät itse enää ole kykeneviä määrittelemään omia avuntarpeitaan ja tekemään päätöksiä omasta hoivastaan ja hoidostaan.

Palveluseteli, asiakasseteli ja henkilökohtainen budjetti ovat välineitä, joiden avulla on mahdollista lisätä joidenkin palveluntarvitsijoiden valinnanvapautta. Palvelujen markkinoistamiseen ja julkisen sektorin tuottamien palvelujen vähentämiseen tähtäävien uudistusten sanotaan tavoittelevan toimivia ja tehokkaita julkisesti säänneltyjä palvelumarkkinoita. Tämä perustuu ajatukselle, että toimivat markkinat muodostuvat ja kehittyvät, kun asiakkaat valitsevat, ja ovat kykeneviä valitsemaan, laadukkaimpia ja kustannustehokkaimpia palveluja, jolloin toimimattomat palvelukonseptit ja laadultaan heikot palvelut karsiutuvat (Daniels \&Trebilcock 2005; Fredriksson ym. 2012,117).

Palveluseteli edistää tällaisia markkinoita ja tasa-arvoista valinnanvapautta vain, jos kunta ei käytä palveluseteliä asiakkaiden ohjaamisen tai kustannussäästöjen välineenä; paikalliset palvelumarkkinat ovat kilpailulliset ja toimivat; sekä valintoja tekevät vanhukset ovat kykeneviä tekemään tietoisia valintoja omista palveluistaan. Valinnanvapauden merkityksen lisääntyminen yleisemmin sosiaali- ja terveyspalveluissa ja erityisesti vanhuspalveluissa on kuitenkin etenevä muutos, joka tuskin pysähtyy tai kääntyy lähitulevaisuudessa. Siksi jatkossa tarvitaan lisää valinnanvapautta ja vanhuspalveluita kriittisesti tarkastelevia tutkimuksia eri tieteenaloilta.

\section{Yhteydenotto: \\ Olli Karsio, YTM, tutkija \\ Yhteiskuntatieteiden tiedekunta, \\ Tampereen yliopisto \\ Sähköposti: olli.karsio@staff.uta.fi}




\section{Kirjallisuus}

Aho, T. (2012). Hankinta- ja sopimuskäytännöt palvelujen ulkoistamisessa. Teoksessa Junnila M., Aho,T., Fredriksson, S., Keskimäki, I., Lehto, J., Linna, M., Miettinen, S. \& Tynkkynen, L-K. (toim.), Sitä saa mitä tilaa: Tilaaja-tuottajatoimintatavan kehittyminen sosiaali- ja terveyspalveluissa (s. 118-135). Raportti 42/2012. Helsinki: THL.

Alastalo, M., Åkerman, M. \& Vaittinen, T. (2017). Asiantuntijahaastattelu. Teoksessa Hyvärinen, M., Nikander, P. \& Ruusuvuori, J. (toim.), Tutkimushaastattelun käsikirja (s. 214-232). Tampere: Vastapaino.

Anttonen, A. (2009). Hoivan yhteiskunnallistuminen ja politisoituminen. Teoksessa Anttonen, A., Valokivi, H. \& Zechner, M. (toim.), Hoiva Tutkimus, politiikka ja arki (s. 54-98). Tampere: Vastapaino.

Ascoli, U. \& Ranci, C. (2003). Dilemmas of the Welfare Mix: The New Structure of Welfare in an Era of Privatization. New York: Plenum Publishers.

Bertelsen, T. M. \& Rostgaard, T. (2013). Marketisation in eldercare in Denmark: free choice and the quest for quality and efficiency. Teoksessa Meagher, G. \& Szebehely, M. (toim.), Marketization in Nordic Eldercare: A Research Report on Legislation, Oversight, Extent and Consequences (s. 127-162). Stockholm Studies in Social Work 30. Stockholm: Stockholm University.

Bogner, A., Littig, B. \& Menz, W. (toim.) (2009). Interviewing experts. Basingstoke. New York: Palgrave Macmillan.

Braun, V. \& Clarke, V. (2006). Using thematic analysis in psychology. Qualitative Research in Psychology, 3, 77-101. doi:10.1191/1478088706qp063oa.

Carnoy, M. (1998). National voucher plans in Chile and Sweden: Did privatization reforms make for better education? Comparative Education Review, 42, 309-337. doi:10.1086/447510.

Chon, Y. (2013). A qualitative exploratory study on the service delivery system for the new long-term care insurance system in Korea. Journal of Social Service Research, 39(2), 188-203. doi:10.1080/01 488376.2012.744708.

Clarke, J., Newman, J. \& Westmarland, L. (2008). The Antagonisms of Choice: New labour and the reform of public services. Social Policy and Society, 7(2), 245-253. https://doi.org/10.1017/ S1474746407004198.
Daniels, R. J. \& Trebilcock, M. J. (2005). Rethinking the welfare state: the prospects for government by voucher. London: Routledge.

Defourny, J., Henry, A., Nassaut, S. \& Nyssens, M. (2010). Does the mission of providers matter on a quasi-market? The case of the Belgian 'service voucher' scheme. Annals of Public and Cooperative Economics, 81, 583-610. doi:10.1111/j.14678292.2010.00423.x.

Erlandsson, S., Storm P., Stranz A., Szebehely M. \& Trydegård G. (2013). Marketising trends in Swedish eldercare: competition, choice and calls for stricter regulation Teoksessa Meagher, G. \& Szebehely, M. (toim.), Marketization in Nordic Eldercare: A Research Report on Legislation, Oversight, Extent and Consequences (s. 23-84). Stockholm Studies in Social Work 30. Stockholm: Stockholm University.

Fotaki, M. (2009). Are all consumers the same? Choice in health, social care and education in England and elsewhere. Public Money E० Management, 29(2), 87-94. http://dx.doi. org/10.1080/09540960902767956.

Francis, T. R. \& Abel, E. M. (2014). Redefining success: a qualitative investigation of therapeutic outcomes for non-completing drug court clients. Journal of Social Service Research, 40(3), 325-338. doi:10.1080/01488376.2013.875094.

Fredriksson, S., Junnila M. \& Tynkkynen L-K. (2012). Palvelujen hankinta yksityisiltä palveluntuottajilta. Teoksessa Junnila M., Aho,T., Fredriksson, S., Keskimäki, I., Lehto, J., Linna, M., Miettinen, S. \& Tynkkynen, L-K. (toim.), Sitä saa mitä tilaa : Tilaaja-tuottaja-toimintatavan kebittyminen sosiaali- ja terveyspalveluissa (s. 89-117). Raportti 42/2012. Helsinki: THL.

Friedman, M. (1955). The role of government in education. Teoksessa Solo, R. A. (toim.) Economics and the Public Interest. NJ: Rutgers University Press.

Friedman, M. (1997). Public Schools: Make Them Private. Education Economics, 5(3), 341-344. doi:10.1080/09645299700000026.

Glendinning, C. (2008). Increasing Choice and Control for Older and Disabled People: A Critical Review of New Developments in England. Social Policy E Administration, 42(5), 451-469.

Greve, B. (2009). Can Choice in Welfare States Be Equitable? Social Policy and Administra- 
tion, 43(6), 543-556. doi:10.1111/j.1467-9515. 2009.00679.x.

Hakala, T. \& Weckström, J. (2011). Palveluseteli 2000-luvun asialistoilla. Teoksessa Niemelä, M. \& Saari, J. (toim.), Politiikan polut ja byvinvointivaltion muutos (s. 232-253). Helsinki: Kelan tutkimusosasto.

Hallitusohjelma (2015). Ratkaisujen Suomi. Pääministeri Juha Sipilän hallituksen strateginen ohjelma 29.5.2015. http://valtioneuvosto.fi/documents/10184/1427398/Ratkaisujen+Suomi_ FI_YHDISTETTY_netti.pdf/801f523e-5dfb45a4-8b4b-5b5491d6cc82 (haettu 2.5.2015).

HE 47/2017 (2017). Hallituksen esitys eduskunnalle laeiksi asiakkaan valinnanvapaudesta sosiaali- ja terveydenhuollossa sekä valtiontalouden tarkastusvirastosta annetun lain 2 §:n muuttamisesta.

Hirschman, A. O. (1970). Exit, Voice and Loyalty. Responses to Decline in Firms, Organizations and States. Cambridge, Massachusetts: Harvard University Press.

Hoppania, H-K., Karsio, O., Näre, L., Olakivi, A., Sointu, L., Vaittinen, T. \& Zechner, M. (2016). Hoivan arvoiset: Vaiva ybteiskunnan ytimessä. Helsinki: Gaudeamus.

Junnila, M., Hietapakka, L. \& Whellams, A. (toim.) (2016). Hallintoalamaisesta aktiiviseksi valitsijaksi. Valinnanvapauden muotoutuminen sote-palveluissa. Helsinki: THL.

Karsio, O. \& Anttonen, A. (2013). Marketisation of eldercare in Finland: legal frames, outsourcing practices and the rapid growth of for-profit services. Teoksessa Meagher, G. \& Szebehely, M. (toim.), Marketization in Nordic Eldercare: $A R e-$ search Report on Legislation, Oversight, Extent and Consequences (s. 85-126). Stockholm Studies in Social Work 30. Stockholm: Stockholm University.

Kuusinen-James, K. (2012). Tuoko palveluseteli vapautta? Tutkimusjulkaisu -sarjan julkaisu nro 68. Helsinki: KAKS -Kunnallisalan kehittämissäätiö.

Kuusinen-James, K. (2016). Setelipeliä. Tutkimus palveluseteliä säännöllisessä kotihoidossa käyttävien iäkkäiden henkilöiden valinnanvapaudesta. Valtiotieteellisen tiedekunnan julkaisuja 2016:32. Helsinki: Helsingin yliopisto.

Kuusinen-James, K. \& Seppänen, M. (2013). Ikääntyvät palvelusetelin käyttäjät valintatilanteissa: kuluttajia vai näennäiskuluttajia? Janus, 21(4), 314-329.
Kremer, M. (2006). Consumers in charge of care: The Dutch personal budget and its impact on the market, professionals and the family. European Societies, 8(3), 361-83. doi:10.1080/14616690600822006.

Kröger, T., Karisto, A. \& Seppänen, M. (2009). Sosiaalityö vanhuuden edessä. Teoksessa Seppänen, M., Karisto, A \& Kröger, T. (toim.), Vanhuus ja sosiaalityö. Sosiaalityö avuttomuuden ja toimijuuden välissä (s. 7-18). Jyväskylä: PS-kustannus.

Kvist, J. \& Greve, B. (2011). Has the Nordic Welfare Model Been Transformed? Social Policy E Administration, 45(2), 146-160. doi:10.1111/j.14679515.2010.00761.x.

Laki sosiaali- ja terveydenhuollon palvelusetelistä 2009/569.

Lehto, J. \& Tynkkynen, L-K. (2013). Älykkäästi suunnitellut sosiaali- ja terveydenhuollon markkinat? Yhteiskuntapolitiikka, 78(6), 605-617.

Linnosmaa, I., Seppälä, T., Klavus, J. \& Oksanen, T. (2012). Palvelusetelit sosiaalipalveluissa: Tuloksia Helsingin kaupungin palveluseteleistä sekä tuottajien palvelusetelikokemuksista. Teoksessa Linnosmaa, I. (toim.), Palvelusetelit sosiaalipalveluissa (s. 7-41). Terveyden ja hyvinvoinnin laitos: Raportti 53/2012. Helsinki: THL.

Lith, P. (2013). Yksityiset sosiaali- ja terveyspalvelut. Raportti yksityisestä palvelutarjonnasta ja yritysten kasvusta sekä julkisista hankinnoista ja toiminnan kehittämisestä sosiaali- ja terveyspalveluissa. TEM raportteja 34/2013. Helsinki: Työ- ja elinkeinoministeriö.

Nemlander, A. \& Sjöholm, M. (2012). Selvitys palvelusetelin käytöstä kuntien ja kuntayhtymien sosiaali- ja terveydenhuollon palveluissa tammibelmikuussa 2012.

Nemlander, A. \& Sjöholm, M. (2015). Selvitys palveluseteleiden käytöstä kuntien ja ybteistoimintaalueiden sosiaali- ja terveyspalveluissa sekä päivähoidossa-tilanne vuoden 2015 toukokuussa. Helsinki: Kuntaliitto. 26.4.2017

Newbronner, L., Chamberlain, R., Bosanquet, K., Bartlett, C., Sass, B. \& Glendinning, C. (2011). Keeping personal budgets personal: learning from the experiences of older people, people with mental health problems and their carers. Research Report. Adults'Services Report, 40. Social Care Institute for Excellence.

Newman, J. \& Clarke, J. (2009). Publics, Politics and Power: Remaking the Public in Public Services. London: Sage. 
Newman, J. \& Tonkens, E. (2011). Responsibility, choice and participation. Teoksessa Newman, J. \& Tonkens, E. (toim.), Participation, Responsibility and Choice-Summoning the Active Citizen in Western European Welfare States (s. 179-200). Amsterdam: Amsterdam University Press.

Nguyen, Ha. T.H., Hatta, L., Islama, M., Sloanb, N. L., Chowdhuryc, J., \& Schmidtd,J-O., Hossaind, A. \& Hong W. (2012). Encouraging maternal health service utilization: An evaluation of the Bangladesh voucher program. Social Science E Medicine, 74(7), 989-996. doi:10.1016/j. socscimed.2011.11.030.

Oh, Y. S. (2015). Effects of Voucher System on the Respite Care Service in South Korea: In the View of Social Exchange Theory. Human Service Organizations: Management, Leadership E Governance, 39(3), 208-218. doi:10.1080/23303 131.2015.1015700.

Palola, E. (2011). Valinnanvapauden problematiikasta sosiaalipolitiikassa. Teoksessa Palola, E. \& Karjalainen, V. (toim.), Sosiaalipolitiikka - Hukassa vai uuden jäljillä? (s. 283-309). Helsinki: Unigrafia Oy Yliopistopaino.

Rostgaard, T. (2006). Constructing the care consumer: free choice of home care for the elderly in Denmark. European Societies, 8(3), 443-463. doi:10.1080/14616690600822048.

Scott, J. (2000). Rational Choice Theory. Teoksessa Browning, G., Halcli, A. \& Webster, F. (toim.), Understanding Contemporary Society: Theories of the Present. London: Sage.

Shaw, S. A. (2014). Bridge builders: A qualitative study exploring the experiences of refugees working as caseworkers in the United States. Journal of Social Service Research, 40(3), 284-296. doi:10. 1080/01488376.2014.901276.
Timonen, V., Convery, J. \& Cahill, S. (2006). Care revolutions in the making? A comparison of cash-for-care programmes in four European countries. Ageing and Society, 26, 455-474. doi:10.1017/S0144686X0600479X.

Tuomi,J. \& Sarajärvi, A. (2002). Laadullinen tutkimus ja sisällönanalyysi. Helsinki: Tammi.

Vabø, M. (2006). Caring for people or caring for proxy consumers? European Societies, 8(3), 403422. doi:10.1080/14616690600821990.

Vamstad, J. (2015). Exit, voice and indifference - older people as consumers of Swedish home care services. Ageing and Society, 36, 2163-2181. doi:10.1017/S0144686X15000987.

Van Aerschot, L. (2014). Vanhusten hoiva ja eriarvoisuus, sosiaalisen ja taloudellisen taustan ybteys avun saamiseen ja palvelujen käyttöon. Acta Universitatis Tamperensis: 1971. Tampere: Tampere University Press.

Voisin, D. R. \& Bird, J. D. P. (2012). 'You get more respect,' reasons for sex among African American high school youth: a qualitative study. Journal of Social Service Research, 38(3), 392-401. doi:10.10 80/01488376.2012.667062.

Volk, R. \& Laukkanen, T. (2007). Palvelusetelin käyttö kunnissa, Sosiaali- ja terveysministeriö. Selvityksiä 2007:38. Helsinki: STM.

Zechner, M. (2012). Palveluseteli vanhushoivan yksityistämisen välineenä. Teoksessa Zechner, M. (toim.), Julkiset sosiaalipalvelut muntoksessa. Markkinat, mittarit ja ennakointi (s. 47-68). Seinäjoki: Anja Mäntylän rahasto.

Zechner, M. (2017) Vastuutetut omaishoitajat markkinoilla. Gerontologia, 31(3). 